\title{
INTRODUCTION AND KEYNOTE
}

\section{JUDGE SHEILA ABDUS-SALAAM* \\ Introduction by ELISE LOPEZ ${ }^{* *}$}

Elise Lopez: My name is Elise Lopez, and I am the president of Empowering Women of Color for the 2016-2017 year. It's so wonderful to see you all here. This is our third annual Empowering Women of Color Conference. Each year, we get better attendance and more engagement. We are joined by our cosponsors: the Columbia Journal of Gender and Law, the African-American Policy Forum, and the Center for Intersectionality and Social Policy Studies.

Our theme this year is Double-Consciousness. It's really a theme that strikes at the core of what our group stands for.

It's about being an advocate both for ourselves in the legal and professional world, but also being a mentor to other women of color. It's also about striking that balance between fitting into this generations-old institution of legal practice, but also pushing boundaries and keeping the dialogue going about issues that are relevant to women of color.

We've brought together a wonderful panel of practitioners, scholars, and members of the judiciary. I'm very excited to hear what they have to share with us today about their experiences and the wisdom that they have gained along the way. Opening our conversation is our keynote speaker, the Honorable Sheila AbdusSalaam, Associate Judge of the New York Court of Appeals.

She is a graduate of Barnard College and also an alumna of our very own Columbia Law School. Upon graduation, she began her legal career as a staff

\footnotetext{
(C) 2018 Abdus-Salaam and Lopez. This is an open access article distributed under the terms of the Creative Commons Attribution License, which permits the user to copy, distribute, and transmit the work provided that the original author(s) and source are credited.

* Judge Sheila Abdus-Salaam was an Associate Judge of the New York State Court of Appeals from 2013-2017.

** Elise Lopez, J.D. candidate 2018, served as 2016-2017 President of Empowering Women of Color at Columbia Law School.
} 
attorney at East Brooklyn Legal Services. Then, she began her work in the judiciary in 1992 in the Civil Court of the City of New York. In 1993, she was elected to the Supreme Court of New York County.

Then, she was appointed an associate justice of the Appellate Division, First Department in March of 2009 by Governor Patterson. In April of 2013, she was nominated by Governor Cuomo to the New York Court of Appeals. She's the first African American woman to serve on the Court of Appeals. We're so very lucky to have her. She has had an illustrious career, and we're excited to hear what she has to say. Please join me in welcoming her.

Judge Sheila Abdus-Salaam: Good morning. Thank you, Elise, for that generous introduction and the warm welcome. This is like a home to me. I've been here so many times since I graduated. As I walked in the door this morning, one of the students here reminded me of a student I knew at Barnard who became the dean of students at Columbia Law School. Now, she's the dean of students at Harvard Law School. I've been here quite a bit over the years. I'm very happy to be here this morning. This theme, Double-Consciousness: Women of Color as Advocates for Ourselves and Others is one that, of course, touches me very personally.

You've heard a little bit about me, but I thought I would share some of my experiences and my thoughts about the profession as I've embarked on my legal career and journey, what I call lifting as I climb and giving back. Mine has been a remarkable climb, as you've heard, all the way from a poor, working-class neighborhood in southeast Washington, D.C. to the Court of Appeals in Albany.

Back in the 1950s and 60s when I was attending still-segregated public schools more than a decade after the United States Supreme Court's landmark Brown v. Board of Education of Topeka ${ }^{1}$ decision, some might have thought my ascension to such lofty heights was impossible. Even I, sometimes, have found it hard to believe my improbable good fortune in becoming the first African American woman to serve on our state's highest court in its 169-year history.

There is that double-consciousness. Why didn't I think I would get there? I have to say my mother thought nothing was impossible. She would not have been surprised that I was there. Unfortunately, she did not live to see me get there, 
although she did see me get on the bench. My family was one of those who could have benefited from free or low-cost legal services. We had no access to lawyers and no personal relationships with any.

My introduction to the legal system and its impact was through watching television. Two of my favorite programs were East Side/West Side, ${ }^{2}$ about a Manhattan neighborhood law office, and Perry Mason, ${ }^{3}$ about the brilliant criminal defense lawyer who never lost a case. To show you just how unfamiliar with lawyers I was, I thought the character on East Side/West Side - played by the venerable actress Cicely Tyson - who sometimes went to court was a lawyer.

In actuality, she was a social worker. I believe Claire Huxtable on The Cosby Show ${ }^{4}$ in the 1980s was the first black woman lawyer or character in a television program. Now, there are several black lawyers on television. Some are fictional characters, and some are real lawyers helping to educate the viewing audience about legal issues. Today's young television fans can choose from any number of potential role models.

One of the hottest shows, I understand, is the Shonda Rhimes' production on $\mathrm{ABC}$, How to Get Away with Murder, ${ }^{5}$ starring the Oscar and Tony award-winning actress, Viola Davis. As some of you may know, she plays a criminal law professor and practicing criminal defense attorney who, like Perry Mason, never loses a case. You will be hearing today from several distinguished women law professors of color, which was not the case when I was a student here. Oh, the progress we have made.

Fortunately for me as a teenager in the late 1960s, I was inspired by a real attorney. Miss Frankie Muse Freeman spoke at my high school about her experiences as an NAACP lawyer in St. Louis, Missouri bringing landmark civil rights cases, successfully challenging segregation in public schools and public housing. At the time she spoke to us, she was a member of the U.S. Commission on Civil Rights, having been named the first woman to serve on the commission

2 East Side/West Side (Talent Associates, United Artists Television \& CBS Television 1963-1964).

3 Perry Mason (Paisano Productions \& CBS Television 1957-1966).

4 The Cosby Show (Carsey-Werner Productions \& Bill Cosby Productions 1984-1992)

5 How to Get Away with Murder (Shondaland, NoWalk Entertainment \& ABC Studios 2014-present). 
by then-President Lyndon Johnson.

I became intrigued with the powerful potential that attorneys had to help people. I decided I wanted to be a lawyer. As you have heard, after graduating from law school, I put my childhood dream into action as an attorney for legal services representing poor families much like my own, as an assistant attorney general in the civil rights and real estate financing bureaus, and as general counsel to the New York City Office of Labor Services, the city's employment agency.

At every stage of my career as a lawyer, I received support and encouragement from my supervisors, co-workers, judges before whom I appeared, and even opposing counsel. They told me I had the right combination of skills and temperament to carry out the responsibilities of a judge. Believing that I could affect even more people's lives with the problem-solving skills I had developed as a lawyer, combined with my ability to calmly listen to and assess the merits of all sides of an issue and to make decisions fairly, I decided to become a judge.

My judicial career began in 1991 when I was elected to a countywide seat on the Civil Court of the City of New York in New York County. Two years later, I was elected to my first fourteen-year term on the Supreme Court and was reelected in 2007. As you heard, in 2009, I was appointed to the Appellate Division, First Department, our intermediate appellate court, by then-Governor David Patterson, and a few years ago to the Court of Appeals by Governor Cuomo.

My two-decade judicial odyssey began as the recipient of a helping hand from someone who saw my potential to become a respected and effective jurist. I tried to incorporate that same ethic in my own life. Whenever I can, I help others to tap the potential that resides within them to become the very best they can be.

That helping hand I got came from the then-county leader and assemblyman of my district, Denny Farrell, who was black and had a plan to diversify the bench in Manhattan by adding more women and judges of color. At the time, Denny chaired the Assembly's Banking Committee.

One of my law school classmates happened to be counsel to that committee. My classmate introduced me to Denny. He encouraged me to submit my application to the Democratic Party Screening Panel for a countywide seat on the civil court. I did that, and as the saying goes, "the rest is history." 
At the time I sought to become a judge, my public interest background and community service set me apart from other candidates. I didn't have to join a political club, the usual route to the bench for lawyers in New York City. I had participated in several legal assistance nights sponsored by Democratic Party clubs, senior citizens centers, churches, tenant associations, and other civic associations in my community; the same kinds of things that advocates do now on a different and bigger level, I think.

Like the lawyers here in this room and the students, I knew that community service is part of an attorney's job description. As poor as we were growing up, my folks taught me to help others. As a teenager, I had heard the clarion call for social justice. When the opportunity arose for me to take the helm of the New York City chapter of the National Conference of Black Lawyers (NCBL) in the late 1970s and early 1980s, I stepped up.

In its heyday, NCBL housed the Community Organization Legal Assistance Project that helped community organizations incorporate and provided legal advice and assistance to their officers and directors. It also had a juvenile rights project that provided legal representation to teenagers charged as adults in the criminal justice system and attempted to educate them about how they can avoid getting caught up in the system.

Similarly, I chaired the board of directors of Harlem Legal Services and joined the New York City chapter of the National Lawyers Skilled Executive Committee. Again, these are collaborations that are a part of being advocates for yourself and for others, and particularly for women. I also became a founding director and first board chair of the Women's Housing and Economic Development Corporation (WHEDco).

WHEDco is a not-for-profit organization headquartered in the Bronx which develops affordable housing for poor women and their families and provides them with job training, education, and skills to become business owners. For the past twenty-one years, I have served on the board of and been an officer of Contemporary Guidance Services, an organization assisting adults with varying developmental abilities to obtain job training and employment so that they can live independently.

Of course, these types of things, as I mentioned, are the things that women are 
drawn to-I think - most because we are service-oriented. We collaborate with others in doing and getting what we need to get done. With all that all of us do every day, there's always more that needs to be done, especially in these difficult economic times when organizations and individuals are struggling just to survive.

As a matter of fact, the Legal Services Corporation - the organization that employed me when I first graduated from law school - is fighting for its life right now. It may, we hope, survive the budget that our current President is anticipating sending to Congress. We all need to do as much as we can, I think, to keep that organization alive.

All we need to do is look at segments of our communities where folks are most vulnerable. Domestic violence victims often need help with the consequences of their victimization, such as losing their children and their jobs and their homes.

As a result of the war on drugs - I should say failed war on drugs - and other law enforcement initiatives that have devastated poor, urban, black, and Latino communities, there are formerly incarcerated men and women who need help getting criminal records expunged or certificates of relief from disabilities so they can become gainfully employed to facilitate their reentry into the community. Some of these folks may wish to become, for example, barbers, beauticians, or other tradespeople, and are prevented from doing so because they cannot obtain a license.

The formerly incarcerated also need help obtaining affordable housing, as do homeless individuals. Just patronizing businesses that employ homeless and formerly incarcerated individuals can be a big help, let alone giving them legal advice or attempting to help them with their legal problems. Small businesses need help, for example, with writing business plans, insurance contracts, applications for loans, or clearing up prior debts.

Immigrants and migrant workers are other vulnerable populations that need legal assistance. More and more, food banks require the assistance of all who can help, including lawyers. These are only a few examples of the areas where women can advocate for others, as well as provide for themselves and do good things for themselves. 
As you can see, the rewards of helping someone who cannot afford a lawyer are usually much greater than the sacrifices made to provide legal assistance without compensation. As you have heard, I place a high priority on community service. Nothing has been more beneficial to my growth and development as a lawyer, a judge, and a person.

As you go through the programs today to talk about the challenges of the double-consciousness of being a woman of color and attempting to be an advocate for yourself and for others, I want you to think about the challenges that we all face in our communities day in and day out. Very recently during the celebration of International Women's Day, the International Association of Women Judges' president sent out a message to the rest of us. She said, "There is an ancient Chinese proverb that says that a woman who is near one river will never be thirsty, and a woman near another woman will never be alone." "F For these reasons, I invite you to keep on working together for other women, for the poorest ones, for those who suffer, for the displaced ones, for young girls, and for the elderly women. Let's work for all those women who only have their own existence and need us. Their right is our duty to fulfill.

I believe that women lawyers, women of color who are lawyers or want to be lawyers are designed for accomplishment, engineered for success, and endowed with seeds of greatness. I leave you with those thoughts as you begin this conference and the next panel that you will hear, and talk about the challenges that you're facing today.

6 A Message from the IAWJ President on International Women's Day, INT'L Ass'N OF Women Judges (Mar. 8, 2017), http://www.iawj.org/message-iawj-president-international-womens-day/ [perma.cc/72JX-WXSX]. 